УДК 347.633: 39

DOI 10.18101/2658-4409-2020-1-26-32

\title{
СОХРАНЕНИЕ ТАЙНЫ УСЫНОВЛЕНИЯ (УДОЧЕРЕНИЯ) ДЕТЕЙ: ОБЫЧАИ НЕКОТОРЫХ НАРОДОВ ЦЕНТРАЛЬНОЙ АЗИИ И СОВРЕМЕННАЯ РЕАЛЬНОСТЬ
}

\section{(C) Доржиева Светлана Владимировна}

кандидат юридических наук, доцент, Бурятский государственный университет имени Доржи Банзарова Россия, 670000, г. Улан-Удэ, ул. Сухэ-Батора, 6

E-mail: dsv_1@mail.ru

Институт усыновления (удочерения) детей у всех народов Центральной Азии используется на протяжении многих столетий и до сих пор не утратил своей актуальности. В статье на примере обычного права бурят и казахов показан ранее действовавший порядок усыновления. Дети-сироты в основном оставались внутри своего рода, получая воспитание, материальное обеспечение. Сохранение тайны усыновления не предусматривалось. Современные нормы семейного законодательства России, Казахстана, Киргизской Республики, Таджикистана, Туркменистана, Узбекистана охраняют тайну усыновления, что, по мнению автора, не всегда соответствует интересам усыновленных. Высказывается мнение, что сохранение тайны усыновления должно зависеть не только от воли усыновителей, но и от желания усыновленных, достигших совершеннолетия. Подчеркивается необходимость формирования в обществе толерантного, уважительного отношения к лицам, усыновившим детей.

Ключевые слова: усыновление; обычное право; тайна усыновления; устройство детей-сирот; воспитание; Центральная Азия.

\section{Для цитирования}

Доржиева C. В. Сохранение тайны усыновления (удочерения) детей: обычаи некоторых народов Центральной Азии и современная реальность // Вестник Бурятского государственного университета. Юриспруденция. 2020. Вып. 1. С. 26-32.

Усыновление (удочерение) является одним из старейших правовых институтов, который не теряет своего значения на протяжении многих веков, разрешая вопросы не только семейного устройства детей-сирот, но и укрепления брачного союза супругов, не имеющих своих детей, создания предпосылок для заботы о них старости, упорядочения наследования и т. д.

Не являются исключением и буряты, у которых со времен обычного права применялась данная форма устройства детей, причем не всегда это было связано с утратой родительского попечения. Зачастую передавали 
C. В. Доржиева. Сохранение тайны усыновления (удочерения) детей: обычаи некоторых народов Центральной Азии и современная реальность

на усыновление детей по просьбе бездетных родственников, кроме этого, усыновляли детей своих многодетных родственников, оказывая им поддержку. В результате ребенок оставался в кровнородственной среде, зная о своих родителях по происхождению, братьях и сестрах, общаясь с ними, получая в случае необходимости поддержку, что способствовало укреплению рода. Усыновлялись и чужие дети. При этом тайна усыновления (удочерения) не сохранялась. Бездетные супруги, усыновившие ребенка, не чувствовали со стороны общества отрицательного отношения к ним из-за отсутствия собственных детей, семья являлась полноценной.

Так, российский просветитель, крупнейший бурятский этнограф М. Н. Хангалов, писал: «У бурят существует обычай усыновлять чужих детей, что, конечно, чаще делают бездетные буряты. Усыновляют как детей, так и взрослых. Усыновленный пользуется имуществом усыновителя как родной сын» [4, с. 195]. Выводом для этого послужили многолетние исследования ученого в конце XIX - начале XX в. юридических обычаев, семейного быта, общественного строя и многих иных областей жизни бурятского населения.

Как отмечают М. К. Абдакимова, С. К. Кенжебаева, С. А. Муликова, издревле «в отношении сирот у казахов существовал прекрасный обычай бауырына басу. К обычаю усыновления в основном прибегали только в том случае, если семья бездетна или появляющееся потомство не выживало. Усыновляли детей близких родственников, обычно старшего или младшего братьев, по предварительной договоренности обеих сторон, но во многих случаях этот обычай распространялся на детей, оказавшихся без родителей. Усыновление, передача и прием ребенка происходили в торжественной обстановке, при участии всех аксакалов аула и родственников. После выполнения обрядовых церемоний клятвенно скреплялся договор» [1]. Следовательно, об усыновлении ребенка было известно широкому кругу лиц.

Несмотря на то, что по обычному праву у бурят и казахов, как и у некоторых других народов Центральной Азии, допускалось усыновление чужих детей, преимущество все же отдавалось усыновлению детей родственников, особенно по отцовской линии. В случае же смерти родителей, «если дети оставались сиротами, усыновить их считалось естественным и почетным даже теми, у кого были свои собственные. Поэтому в бурятских улусах дети-сироты не оставались без призрения. Приемные дети пользовались всеми теми же правами, что и собственные» [2, с. 64].

Аналогичная ситуация была и в Казахстане, так, «потеря детьми одного или двух родителей по разным причинам не приводила их к положению бесправного и лишенного имущества члена общины. Род был обязан сохранить им жизнь, вырастить и наделить имуществом» [1]. 
Следует отметить, что «названные традиции являются актуальными и востребованными в настоящее время, поскольку среди основных задач государственной демографической политики России значатся «укрепление института семьи, возрождение и сохранение духовно-нравственных традиций семейных отношений» ${ }^{1}[3$, с. 18$]$.

К сожалению, в советское время практически у всех народов Центральной Азии, проживавших в СССР, были значительно утрачены традиции предков, что наблюдается и по сей день. Это подтверждается большим количеством детей, воспитывающихся в организациях для детей-сирот, и детей, оставшихся без попечения родителей. Теперь ни у бурят, ни у казахов, как и у многих других народов Центральной Азии, не является зазорным отказаться от своего ребенка в роддоме, ненадлежащим образом выполнять родительские обязанности, не брать на воспитание детей своих родственников, в случае утраты ими родительского попечения и т. д. Все это, конечно же, обусловлено политическими, социальноэкономическими событиями, которыми полна история наших государств. В результате мы видим ослабление родовых связей, утрату выработанных тысячелетиями мер взаимной поддержки и помощи.

Вместе с тем желание знать свое происхождение неистребимо у людей любой национальности. Каждый ребенок-сирота или ребенок, оставшийся без попечения родителей, воспитывающийся в организации для данной категории детей либо находящийся на воспитании в замещающей семье, стремится узнать своих биологических родителей и (или) родственников. Не составляют исключение и усыновленные дети, несмотря на то, что между ними и усыновителями в силу закона складываются такие же правовые отношения, как и между родственниками по происхождению. В отличие от других детей-сирот и детей, оставшихся без попечения родителей, усыновленные дети не могут свободно реализовать право знать своих родителей. Так, сохранение тайны усыновления (удочерения) предусмотрено не только ст. 139 Семейного кодекса Российской Федерации ${ }^{2}$ (далее - СК РФ), но и ст. 102 Кодекса о браке (супружестве) и семье Республики Казахстан ${ }^{3}$, ст. 60 Кодекса Киргизской Республики о де-

\footnotetext{
${ }^{1}$ Об утверждении Концепции демографической политики Российской Федерации на период до 2025 г.: указ Президента РФ от 9 октября 2007 г. № 1351 (ред. 01.07.2014) // СЗ РФ. 2007. 15 окт. № 42. Ст. 5009.

${ }^{2}$ Семейный кодекс РФ от 29 декабря 1995 г. № 223-ФЗ (ред. 02.12.2019 г.) // С3 РФ. 1996. № 1. Ст. 16.

${ }^{3}$ Кодекс Республики Казахстан от 26 декабря 2011 г. № 518-IV «O браке (супружестве) и семье» (ред. 27.12.2019). URL: https://online.zakon.kz/document/?docid $=31102748 \#$ pos $=4 ;-180$ (дата обращения: 23.01 .2020 ).
} 
C. В. Доржиева. Сохранение тайны усыновления (удочерения) детей: обычаи некоторых народов Центральной Азии и современная реальность

тях ${ }^{1}$, ст. 139 Семейного кодекса Республики Таджикистан ${ }^{2}$, ст. 122 Семейного кодекса Туркменистана ${ }^{3}$, ст. 153 Семейного кодекса Узбекистана ${ }^{4}$.

Кроме вышеуказанной причины, усыновленные (удочеренные) дети стремятся раскрыть эту семейную тайну для исключения вероятности вступления в брак со своими близкими родственниками, профилактики или лечения наследственных заболеваний и т. д. Все перечисленное свидетельствует об объективной необходимости знать свои корни, а с учетом прежних устоев народов Центральной Азии общение с родственниками по происхождению означает еще и дополнительную поддержку, что в условиях нестабильного духовного, социально-экономического состояния общества может только приветствоваться. С удовлетворением стоит отметить, что в век урбанизации все еще остаются семьи, которые чтят традиции предков и родственные узы.

На современном этапе в России о возможности «перехода к системе открытого усыновления с отказом от тайны усыновления» было отмечено в ч. 9 п. 3 разд. 5 «Национальной стратегии действий в интересах детей на 2012-2017 гг.»5. В целях реализации указанной стратегии Временной рабочей группой по совершенствованию семейного законодательства Российской Федерации при Координационном Совете при Президенте РФ в п. 47 было внесено предложение «предусмотреть действие принципа тайны усыновления ребенка только для тех случаев, когда усыновители ходатайствуют об установлении тайны усыновления. При этом лица, принимающие решение об усыновлении ребенка, осуществляющие государственную регистрацию усыновления, либо иные лица, которым стало известно об усыновлении ребенка в связи с их профессиональной деятельностью, дают подписку о неразглашении тайны усыновления данного ребенка. Предоставить совершеннолетним усыновленным детям право

1 Кодекс Киргизской Республики о детях от 10 июля 2012 г. № 100 (ред. 24.04.2019). URL: https://online.zakon.kz/Document/?doc_id=31223299\#pos=631;-52 (дата обращения: 20.01.2020).

${ }^{2}$ Семейный кодекс Республики Таджикистан от 13 ноября 1998 г. № 628 (ред. 24.02.2017). URL: https://online.zakon.kz/document/?doc_id=30445181\#pos=825;-56 (дата обращения: 21.01.2020).

${ }^{3}$ Семейный кодекс Туркменистана от 10 января 2012 г. № 258-IV (ред. 01.12.2018). URL: http://www.turkmenistan.gov.tm/?id=779 (дата обращения: 25.01.2020).

${ }^{4}$ Семейный кодекс Узбекистана от 30 апреля 1998 г. № 608-I (ред. 03.12.2019). URL: https://online.zakon.kz/document/?doc_id=30421452\#pos=5;-245 (дата обращения: 22.01.2020).

${ }^{5} \mathrm{O}$ Национальной стратегии действий в интересах детей на 2012-2017 гг.: указ Президента РФ от 1 июня 2012 г. № 761 // СЗ РФ. 2012. № 23. Ст. 2994. 
знать о своих родителях в случае смерти усыновителей» ${ }^{1}$. Это свидетельствует о том, что подход к повсеместному сохранению тайны усыновления понемногу меняется. В связи с изложенным представляет интерес постановление Конституционного суда РФ от 16.06.2015 г. № 15-П «По делу о проверке конституционности положений статьи 139 Семейного кодекса Российской Федерации и статьи 47 Федерального закона “Об актах гражданского состояния” в связи с жалобой граждан Г. Ф. Грубич и Т. Г. Гущиной», согласно которому положения этих статей «не препятствуют предоставлению по решению суда потомкам усыновленного после смерти усыновленного и усыновителей сведений об усыновлении в объеме, необходимом для реализации ими своих конституционных прав и обеспечивающем поддержание баланса конституционно защищаемых ценностей, а также прав и законных интересов участников соответствующих правоотношений ${ }^{2}$.

Из вышеуказанного наблюдается более расширенный подход к сохранению тайны усыновления (удочерения). Остается надеяться на то, что со временем в России совершеннолетние усыновленные и (или) их потомки будут иметь возможность узнать о своем происхождении и при отсутствии согласия усыновителей на раскрытие тайны усыновления (удочерения) как при жизни последних, так и после их смерти, что должно найти свое нормативное закрепление в ст. 139 СК РФ.

В связи с изложенным представляют интерес положения ст. $153 \mathrm{Ce}$ мейного кодекса Узбекистана, согласно которой, «воспрещается без согласия усыновителей, а в случае их смерти - без согласия органа опеки и попечительства ознакомление с содержанием книг регистрации актов гражданского состояния или иных документов, выдача из них выписок или иных сведений, из которых было бы видно, что усыновители не являются родителями усыновленного. Лица, разгласившие тайну усыновления против воли усыновителя или органа опеки и попечительства, несут установленную законом ответственность». Из указанной нормы следует, что в случае смерти усыновителя все же имеется возможность получить

\footnotetext{
1 Экспертное заключение по проекту Концепции совершенствования семейного законодательства Российской Федерации и Предложений по совершенствованию семейного законодательства (принято на заседании Совета при Президенте РФ по кодификации и совершенствованию гражданского законодательства 7 июля 2014 г. № 132-1/2014. Доступ из справ.-правовой системы «КонсультантПлюс».

2 По делу о проверке конституционности положений статьи 139 Семейного кодекса Российской Федерации и статьи 47 Федерального закона «Об актах гражданского состояния» в связи с жалобой граждан Г. Ф. Грубич и Т. Г. Гущиной: постановление Конституционного суда РФ от 16 июня 2015 г. № 15-П. Доступ из справ.-правовой системы «КонсультантПлюс».
} 
C. В. Доржиева. Сохранение тайны усыновления (удочерения) детей: обычаи некоторых народов Центральной Азии и современная реальность

сведения об усыновлении с согласия органа опеки и попечительства. Аналогичное положение предусмотрено и в ст. 122 Семейного кодекса Туркменистана. В России такой внесудебный порядок получения информации об усыновлении фактически отсутствует. Статья 139 СК РФ предусматривает лишь ответственность судей, вынесших решение об усыновлении ребенка, или должностных лиц, осуществивших государственную регистрацию усыновления, а также лиц, иным образом осведомленных об усыновлении, за разглашение тайны против воли его усыновителей. Такие же положения действуют в вышеуказанных нормах Киргизской Республики, Республики Таджикистан, а в ст. 102 Кодекса о браке (супружестве) и семье Республики Казахстан в числе лиц, обязанных сохранять тайну усыновления (удочерения), прямо указаны также родители и родственники.

Полагаем, что в обществе необходимо формировать не просто толерантное, а уважительное отношение к семьям, усыновившим (удочерившим) ребенка, подчеркивая социальную значимость такого благородного поступка. В этом случае у многих граждан, решившихся на усыновление (удочерение), не возникнет желания сохранять данную семейную тайну. Кроме этого, совершенствование института усыновления (удочерения) не должно проходить в отрыве от обычаев и традиций народов. Укрепление родовых связей путем усыновления (удочерения) детей родственников, расширение семей в результате усыновления чужих детей будут только способствовать развитию общества.

\section{Литература}

1. Абдакимова М. К., Кенжебаева С. К., Муликова С. А. Проблема сиротства в Казахстане: дисфункция родительства и кризис духовности [Электронный pecypc] // Международный журнал прикладных и фундаментальных исследований. 2015. Ч. 1, № 9. С. 172-176. URL: https://applied-research.ru/ru/article/view?id=7464 (дата обращения: 15.01.2020).

2. Басаева К. Д. Семья и брак у бурят (вторая половина XIX - начало XX века) / отв. ред. П. Т. Хаптаев. Новосибирск: Наука. Сиб. отд-ние, 1980. 224 c.

3. Доржиева С. В. Приемная семья: прошлое, настоящее, будущее: монография / под общ. ред. А. Н. Левушкина. М.: Проспект, 2018. 208 с.

4. Хангалов М. Н. Собр. соч. Улан-Удэ: Бурят. кн. изд-во, 1958. Т. 1. $551 \mathrm{c}$. 
PRESERVATION OF CONFIDENTIALITY IN CHILD ADOPTION:

CUSTOMS OF SOME PEOPLES OF CENTRAL ASIA AND MODERN REALITY

\section{Svetlana V. Dorzhieva}

Cand. Sci. (Law), A/Prof.,

Dorzhi Banzarov Buryat State University

6 Sukhe-Batora St., Ulan-Ude 670000, Russia

E-mail:dsv_1@mail.ru

The institute of child adoption is a universal practice among all the peoples of Central Asia. The article considers the previous adoption procedure using the example of customary law of Buryats and Kazakhs. Orphans mostly were adopted by their blood kin, who provided an education and financial assistance for them. No provision existed for confidentiality of adoption. Modern regulations of the family legislation in Russia, Kazakhstan, the Kyrgyz Republic, Tajikistan, Turkmenistan, and Uzbekistan protect the confidentiality of adoption, but, in our opinion, it is not always meet the interests of adopted. We express an opinion that the preservation of confidentiality in adoption should depend not only on the will of the adoptive parents, but also on the desire of the adopted, who reached lawful age. The article emphasizes that there is a necessity of tolerant, respectful attitude towards persons adopting children in society.

Keywords: adoption; customary law; confidentiality of adoption; adoption of orphans; education; Central Asia. 